\title{
A Study on the Countermeasure of the Integrated Care Network for the Elderly to Promote Community Cooperation and Connection
}

\author{
Mi-Ran Lee1)
}

\begin{abstract}
In order for elderly facing the weakening of their health functions to maintain a sustainable life in the community, there should be a continuum of institutional care services and caring options such as personal care and long-term care insurance. It is necessary to establish a new service support system that can provide for the needs of the elderly by recovering the elderly care ecosystem centered on the local area and constructing reliable service providers according to the spread of community-based integrated care service systems for the elderly. However, it is very complicated to establish an environment where the elderly can live in the community and this requires various supports. Therefore, this study aims to revitalize cooperation and connection through community city revitalization, residents' organization and capacity building, seek strategies to establish the integrated care network development system, and present basic data.
\end{abstract}

Key words: Sustainability, Care Services, Daily Care, Independent Life of Elderly, Integration

\section{Introduction}

With the increase in the aging speed and the transition to the decentralization and marketization of care services, it is urgent to create a sustainable care environment for the elderly. However, it is very complicated to establish an environment where the elderly can live in the community and this requires various supports[1]. Changes in family relations, suicide among the elderly, and social isolation and death from loneliness led to an increase in social interest in the care of the elderly. Even though the welfare expenditure growth rate shows a much higher increase than the OECD average from 2005 to 2009 and social security systems such as primary, secondary, and tertiary social safety nets have been established, it did not reach to the local residents.

Received(December 24, 2018), Review Result(1st: January 9, 2019, 2nd: February 21, 2019), Accepted(March 10, 2019)

1) (Professor) 49104 Dept. Social Welfare, Kosin Univ., 194 Wachi-Ro Yeongdo-Gu, Busan, Korea email: dsmr0815@naver.com 
A Study on the Countermeasure of the Integrated Care Network for the Elderly to Promote Community Cooperation and Connection

Notably, the new social risks such as the diversification and complexity of individual needs, social isolation, death from loneliness, and suicide suggest that an integrated approach is needed for the care of the elderly at the local level, unlike the existing support methods. Community-based care is receiving attention as one of the countermeasures to such a demand, and what is important in providing community-based care is to recognize the problems of individuals and families as local problems and organically link institutional and local areas.

A continuum of services and care options are needed to cover the individual care and institutional care, such as long-term care insurance systems in order, for elderly facing the possibility of declining physical and mental health to allow aging within their communities[2]. In this context, it is very important to establish an integrated care system at the community level and various aspects and processes can be derived depending on the local conditions, the environment, the organization of the care system, and the method of operation.

What is important in the care of the elderly is to support their old life through care from familiar neighbors and institutions in the community where the elderly have lived. Based on the community, independent aging becomes possible when the daily care and emotional support utilizing the human and material resources of the area are linked together. Independent life for the elderly is possible if daily care and emotional support are provided linked with the local human and material resources in a community-based manner.

It is necessary to establish a new service support system that can provide for the needs of the elderly by recovering the elderly care ecosystem centered on the local area and constructing reliable service providers according to the spread of community-based integrated care service systems for the elderly.

Therefore, this study aims to revitalize cooperation and connection through community city revitalization, residents' organization and capacity building, seek strategies to establish the integrated care network development system, and present basic data.

\section{Review and Analysis}

In 2000, the total population of elderly accounted for more than $7 \%$ of the total population in Korea, entering an 'aging society'. In 2019, we are entering an 'aged society' (14\%). Some regions have already entered a 'super aged society' $(20 \%)$, and by 2026, Korea as a whole is expected to become a super aged society[3]. 
[Table 1] Number of Elderly Living Alone and Ratio

(Unit: 1,000 households, \%)

\begin{tabular}{|c|c|c|c|c|c|}
\hline Category & 2010 & 2015 & 2025 & 2035 & $\begin{array}{c}\text { Annual average } \\
\text { number of increased } \\
\text { households }\end{array}$ \\
\hline $\begin{array}{c}\text { Number of elderly } \\
\text { living alone }\end{array}$ & 1,056 & 1,379 & 2,248 & 3,430 & 95 \\
\hline $\begin{array}{c}\text { Ratio of elderly living } \\
\text { alone out of single } \\
\text { households }\end{array}$ & 25,4 & 27,3 & 34,3 & 45,0 & 95 \\
\hline
\end{tabular}

Source: National Statistical Office, 「Future household estimation: 2010 2035」(2012. 4. 26).

Current public care provided to the elderly include long-term care insurance, care services for the elderly, and elderly home care service from the Ministry of Health and Welfare. These are provided differently according to the level of protection and needs of users. In addition, health-related services and home care services are provided in the local community[Table 2]. However, despite the fact that the public care system has infrastructure in most parts, there are still other blind spots and difficulties in accessing the system due to limitations of information sharing among agencies, segmentation of services, and confusion of similar care services[4].

[Table 2] Health and Welfare Project for the Elderly

\begin{tabular}{|c|c|c|c|}
\hline \multirow{4}{*}{ Division } & Social insurance & State aid business & Local transfer business \\
\cline { 2 - 5 } & $\begin{array}{c}\text { National Health } \\
\text { Insurance Corporation }\end{array}$ & Ministry of Health and Welfare & Local Government \\
\hline $\begin{array}{c}\text { Health } \\
\text { insurance }\end{array}$ & $\begin{array}{c}\text { Long-term care } \\
\text { insurance for the } \\
\text { elderly }\end{array}$ & Dementia checkup business & $\begin{array}{c}\text { Elderly welfare facility } \\
\text { (medical care) }\end{array}$ \\
\cline { 2 - 5 } Income \\
guarantee
\end{tabular}

Source: Ministry of Health and Welfare, 2017 Elderly health and welfare project guide 
A Study on the Countermeasure of the Integrated Care Network for the Elderly to Promote Community Cooperation and Connection

This is because the care for daily life has limitations in responding to the demand as public care, and there is a difference between the contents of care needed by the individual and characteristics of old age and the public care system provided by standardized methods such as period and urgency. Cooperative structures among neighbors are very important for emotional support and crisis interventions that are difficult to categorize clearly such as physical and housework support.

However, even though the complexity of content and form of support has increased in accordance with the care policy, empirical analysis is limited in terms of local characteristics, roles and interactions between providers, resident involvement, and activity level. In addition, current elderly care is focused on caring support. Also, a desirable care system should have a structure in which the available institutional services and the caring activities that can be participated in within the community complement each other[Fig. 1].

[Table 3] Elderly Care Support Service[5]

\begin{tabular}{|c|c|c|c|c|}
\hline Type & Visiting services & $\begin{array}{c}\text { Community } \\
\text { services }\end{array}$ & Other services & Facilities services \\
\hline $\begin{array}{l}\text { Long-term } \\
\text { care } \\
\text { insurance }\end{array}$ & $\begin{array}{l}\text { Home treatment } \\
\text { Home bathing } \\
\text { Home care }\end{array}$ & $\begin{array}{l}\text { Day and night } \\
\text { protection service } \\
\text { Short-term } \\
\text { protection service }\end{array}$ & $\begin{array}{c}\text { Welfare } \\
\text { equipment service }\end{array}$ & $\begin{array}{c}\text { Elderly care } \\
\text { facilities } \\
\text { Elderly group home }\end{array}$ \\
\hline $\begin{array}{l}\text { Elderly care } \\
\text { service }\end{array}$ & $\begin{array}{l}\text { Basic care service for } \\
\text { the elderly } \\
\text { Comprehensive care } \\
\text { service for the elderly } \\
\text { (Home treatment ) }\end{array}$ & $\begin{array}{l}\text { Comprehensive } \\
\text { care service for the } \\
\text { elderly } \\
\text { (Day and night } \\
\text { protection) }\end{array}$ & $\begin{array}{l}\text { Basic care service } \\
\text { for the elderly }\end{array}$ & \\
\hline \multirow[b]{2}{*}{$\begin{array}{l}\text { Elderly } \\
\text { home care } \\
\text { service }\end{array}$} & $\begin{array}{l}\text { Elderly home care } \\
\text { service }\end{array}$ & & $\begin{array}{l}\text { Elderly home } \\
\text { care service }\end{array}$ & \\
\hline & $\begin{array}{l}\text { Elderly home care } \\
\text { service(Welfare center } \\
\text { for the elderly) }\end{array}$ & & $\begin{array}{l}\text { Elderly home } \\
\text { care service } \\
\text { (Welfare center } \\
\text { for the elderly) }\end{array}$ & \\
\hline $\begin{array}{l}\text { Elderly } \\
\text { housing } \\
\text { policy }\end{array}$ & & & & $\begin{array}{c}\text { Nursing home } \\
\text { Elderly group home } \\
\text { Elderly welfare } \\
\text { housing }\end{array}$ \\
\hline
\end{tabular}

It is very likely that the problems of the elderly living alone, such as death by loneliness, will become a serious social problem within 10 years. As a result, the necessity of social services is increasing to provide a check on service and housekeeping service according to the needs of the elderly living alone and link various welfare services of the community. 
This social service is an elderly care service based on Article 27-2 of the 「Welfare of Older Persons Act $\lrcorner$. Among the elderly care services, the basic care service for the elderly is a national project that provides various welfare services to elderly people aged 65 or older who are selected according to certain criteria such as income or social contact level. In addition, the comprehensive care service for the elderly is a service for elderly people aged 65 or older who are selected by considering their health status (Grade A and B, not a recipient of long-term medical care) and household income. The visiting service or daytime protection service is provided as a voucher type through a national project[Table 4].

[Table 4] Basic Care Services for the Elderly vs. Elderly Care Comprehensive Service

\begin{tabular}{|c|c|c|}
\hline Division & Basic service & Comprehensive Service \\
\hline $\begin{array}{l}\text { Provided } \\
\text { personnel }\end{array}$ & Living alone senior citizen living alone & old man Caregiver \\
\hline Subject & $\begin{array}{l}\text { An elderly person living alone on a } \\
\text { low income level }\end{array}$ & $\begin{array}{l}\text { A low-income elderly person who is } \\
\text { judged to be } A \text { or } B\end{array}$ \\
\hline Service contents & $\begin{array}{l}\text { Safety check, life education, service } \\
\text { connection }\end{array}$ & $\begin{array}{l}\text { Support for person / activity } \\
\text { Support for daily life }\end{array}$ \\
\hline Delivery method & $\begin{array}{l}\text { Dispatching a life support agent } \\
\text { employed by the government-funded } \\
\text { elderly welfare center }\end{array}$ & $\begin{array}{l}\text { Provided by the elderly carer of the } \\
\text { private long-term care center }\end{array}$ \\
\hline Financial source & $\begin{array}{c}\text { Support labor cost and business expense } \\
\text { of one providing manpower matching } \\
\text { national and local expenses }\end{array}$ & $\begin{array}{l}\text { Supporting a voucher scheme for } \\
\text { matching the national treasury and } \\
\text { local expenses and a small amount of } \\
\text { money charge }\end{array}$ \\
\hline
\end{tabular}

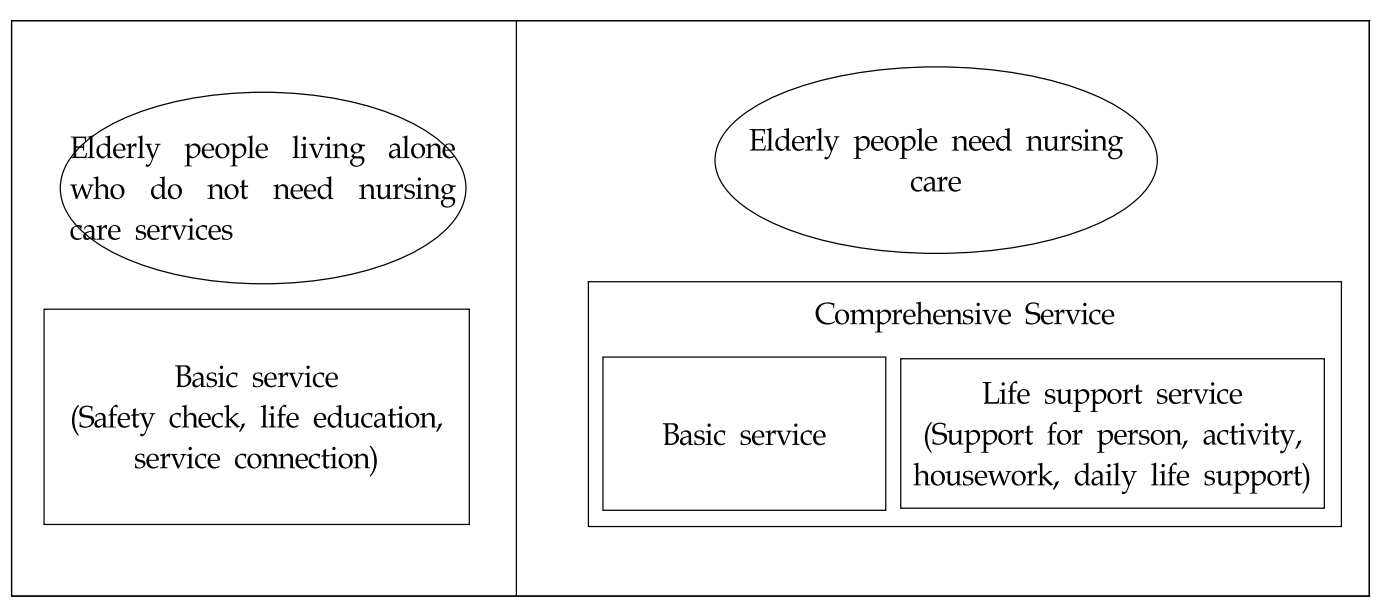

[Fig. 1] Senior Care Service System 


\section{A Study on the Countermeasure of the Integrated Care Network for the Elderly to Promote Community Cooperation}

and Connection

The problems of the current elderly care service project are as follows[Table 5].

First, the selection criteria for the subject of the welfare services are too complicated and fragmented in the process of the administration. In addition, there was a welfare blind spot that was neglected because the service overall management system did not function properly. Also, the service was applied uniformly without reflecting differences between regions, and there was a problem of administrative waste caused by lack of information sharing among the organizations of the welfare delivery system.

Second, in terms of providing care services, there was difficulty of securing care workforce in many institutions. In addition, the unit price of the comprehensive service was set too low, and the problem of the institutional operation was pointed out. In addition, the problems of the heavy workload of caregivers, the lack of security for the service provider, and the conflict between workers due to the service integration were suggested.

Third, in terms of supply and demand of caring service, there was a possibility that elderly in remote and underdeveloped areas would not be able to receive service. Also, since the service staff provide services to the elderly with mild dementia, these elderly people were more likely to be discriminated against in the service supply, and inappropriate behavior of the service recipient and their families to the elderly caregivers was also found.

In order to solve these problems, first, it is necessary to integrate services that are overly fragmented in the execution of the administrative agency and to apply this considering regional differences. In addition, it is necessary to share the service recipient information by securing a service overall management system. There is also a need to enhance the status of public services by enhancing the public nature of care service.

[Table 5] Discussion on the Analysis of the Comprehensive Care Service Policy for the Elderly

\begin{tabular}{|c|c|c|}
\hline Side & Analytical Criteria & Discussion Point \\
\hline Object & $\begin{array}{l}\text { Eligibility Criteria for } \\
\text { Service Target }\end{array}$ & $\begin{array}{l}\text { - Based on superficial universalism principle but practically } \\
\text { according to selectivityism } \\
\text { - Service users are low due to the criteria of selection } \\
\text { (income standard and health status). In other words, the rate } \\
\text { of users is low compared to those who need medical } \\
\text { treatment }\end{array}$ \\
\hline Salary & $\begin{array}{c}\text { Autonomy and limitations } \\
\text { of choice Variety of pay } \\
\text { content }\end{array}$ & $\begin{array}{l}\text { - Ambiguity in delivering services because the service content } \\
\text { is not standardized. } \\
\text { - There are a lot of overlapping with the elderly business } \\
\text { mainly in the home, and there is not a variety of services to } \\
\text { meet specific needs. } \\
\text { - The right to choose a service due to the consumer support }\end{array}$ \\
\hline
\end{tabular}




\begin{tabular}{|c|c|c|}
\hline & & $\begin{array}{c}\text { method, while the limited service content does not guarantee } \\
\text { the choice. }\end{array}$ \\
\hline $\begin{array}{l}\text { Delivery } \\
\text { System }\end{array}$ & $\begin{array}{l}\text { Service delivery system } \\
\text { and accessibility }\end{array}$ & $\begin{array}{c}\text { - The supply system changes according to the marketization } \\
\text { principle, namely the problems caused by the conversion of } \\
\text { the voucher system or registration system (excessive } \\
\text { competition, regional imbalance). } \\
\text { - Reducing the role of national and local governments as } \\
\text { supply system changes }\end{array}$ \\
\hline Finance & $\begin{array}{l}\text { The financial burden of } \\
\text { the country }\end{array}$ & $\begin{array}{l}\text { - Budget burden due to increase } \\
\text { - Priority selection based on budget, } \\
\text { Targeted persons are placed in a blind spot. }\end{array}$ \\
\hline
\end{tabular}

Second, in terms of providing care service, the treatment of the elderly care workforce should be improved with reduced workload by increasing caregivers while total service cost should reflect the reality of the current circumstances.

Lastly, it is necessary to prevent the alienation of elderly people by paying long distance transportation expenses considering the reality in terms of the supply and demand of the care service. It is necessary to provide pre-education for elderly care service recipients and their family to improve their perception of elderly care service workers. In the case of mistreatment, it is necessary to consider measures to remove their eligibility for the service.

As the elderly care service is expanded, the division of the elderly care delivery system is intensified because the government did not develop the service sequentially and systematically with a comprehensive plan for the development of elderly care service. Unlike recent services for the elderly living alone or elderly with dementia, they have not been able to systematically develop services in response to immediate social issues while taking into consideration the existing services and the principles of integration, accessibility, and inclusiveness. This may have been due to the efforts of the Ministry of Health and Welfare to expand the budget by expanding various projects individually.

The fundamental way of solving the fragmentation of such a care delivery system is to simplify the complex system by integrating the existing similar services. The integration of delivery systems should be decided carefully.

Microscopically, the following improvements will be needed in relation to this study. First, it is necessary to respond actively to the illegal activities of suppliers, which are obstacles to mutual friendly cooperation due to the excessive competition of elderly care service providers. Second, the role of local governments is necessary for the cooperation between the local suppliers and various institutions through the activation of the community welfare council. Third, local governments should play an active role in securing the necessary services based on 
A Study on the Countermeasure of the Integrated Care Network for the Elderly to Promote Community Cooperation and Connection

the lists of elderly who are not recipients of benefits and coordinate the actual service to provide. For this purpose, it is necessary to arrange and utilize the personnel to carry out the role of coordinators such as coordination, adjustment and communication of formal and informal services, and resources for the elderly in the community. Fourth, the current long-term care insurance system is centered on providing nursing care services, and local governments are not paying enough attention. Therefore, it is necessary to improve the reality that the service provision is not achieved at community level, such as elderly people's social participation. To this end, the central government should provide public officers related to elderly welfare and grant local governments appropriate autonomy and authority.

A community-based comprehensive care service is necessary for the users who have caring needs to have an easy access channel, and as the control tower for the providers in certain local units. A community-based comprehensive care service base (platform) for the elderly is a user's access point. It also enables close communication with users and their families, comprehensive understanding of user care needs, and plays a role in organizing, linking, and managing care services for various providers.

The detailed roles of the community-based comprehensive care service base (platform) are summarized as follows. First, the base (platform) is a comprehensive response organization for user care needs. Second, the base is the production and communication of information by various subjects. It is not an exclusive information providing space from one provider, but a place where various providers and users exchange information freely. Third, the base is a place where a network of various providers takes place. The services needed to live and reproduce daily life are more diverse than you might think.

There are also services that do not seem directly related to care service. While various service providers are networking, the base plays a role as a control tower for the core hub. It is necessary to support the formation of social economic organization caring clusters so that the base of caring service organization plays a hub role and the other constituent institutions of a caring cluster are loosely combined to contribute to the integrated care of the elderly.

\section{Conclusion and Suggestion}

The purpose of this study is to analyze the systematic framework of the relationship between the nation and the region, based on the results of existing literature on regional regeneration and community care. As a result, regional regeneration mainly consists of contents for physical 
infrastructure improvement, social integration, and economic growth. These various community urban regeneration contents mainly induce community contextual changes such as ensuring the residential stability and community safety of the local community, improving the convenience level of the community, improving the walkable community, restoring the community, and increasing the sense of belonging to the community. Such a contextual change will directly and indirectly affect the physical, psychological, and social health of residents in the area, which will ultimately affect the satisfaction of individual's lives.

The provision of care in the community through social economic organization is raised as a practical model to cope with the decentralization and marketization of social services, blind spots in the institutional welfare system, the problem of fragmentation, and the discontinuity of social welfare delivery system. Services for the elderly require a community-based approach.

The community-based model is an approach that encourages community problem solving by establishing a voluntary and collaborative community of diverse commercial and nonprofit organizations active in the community[6]. In other words, unlike the market or the nation, community associations can define their own community needs, establish a community operating principle to solve them, and link them with community systems that support it. Therefore, it is very likely that social economic organizations can contribute to community-based models. A variety of social economic organizations such as cooperatives, social enterprises, and village enterprises take collective action to maximize network attributes to create a virtuous circle of production and consumption within the community[7]. In addition, it eliminates blind spots in the area, establishes a virtuous circle of local production and consumption through the work community, and realizes the social economy through solidarity with local resident's businesses[8].

The provision of care services through community-based social economic organizations in this way is important in terms of the necessity of establishing a sustainable care providing system, eliminating blind spots and improving service quality, creating decent jobs, and the social integration of local residents[9]. This is because cooperating with each other is possible based on the community, and a service user becomes a producer in a comparative relationship in which the residents participate, enabling receiving a flexible service that appropriately responds to the needs of the local residents and the residents themselves.

At the same time, it is possible to increase the voluntary participation of users and service delivery personnel, eliminate the blind spots caused by the inability of the market and the nation to provide services, and deliver quality services reflecting user needs[10].

Therefore, it is necessary to create a structure that forms a relationship in which social 
A Study on the Countermeasure of the Integrated Care Network for the Elderly to Promote Community Cooperation and Connection

economic organizations and local residents are mutually benefiting through the establishment of a 'community-based comprehensive care service for the elderly'. It is necessary to build a virtuous cycle care ecosystem where a user receiving a community-based comprehensive care service support system is not a passive beneficiary but a new provider.

In spite of the necessity of integrated care for the elderly through social economic organization, it is being implemented only in a limited area, and even though it is carried out, it does not show a successful model in all regions. Therefore, it is necessary to study methods to spread a community-based integrated care ecosystem for the elderly through social economic organization.

This study examined the problem of the current social service delivery system with focus on elderly care where social service has been expanded and suggested the direction of the reorganization of the governance structure to build user-centered integrated case management to solve problems. It is expected that the reorganization of the delivery system centered on integrated case management through the reorganization of the community governance system will be not only a realization of service guarantee via the Framework Act on Social Security but also an enhancement of the service quality and effectiveness of the delivery system for solving the fragmented supply structure, service accessibility, social service quality, and manpower problems, as well as establishing a user-centered integrated case management system as a local government-centered governance structure.

This means that it will create a structure where services are prepared for residents based on their needs with a single request for help to the integrated case management organization, and although it may not be enough, they can receive a variety of help at the appropriate level to meet the needs.

\section{References}

[1] C.-W. Lui, J.-A. Everingham, J. Warburton, M. Cuthill, H. Bartlett, What makes a community age-friendly: A review of international literaturem, Australasian Journal on Ageing, (2009), Vol.28, No.3, pp.116-121, DOI: $10.1111 / j .1741-6612.2009 .00355 . x$.

[2] F. Tang, J. G. Pickard, Aging in Place or Relocation: Perceived Awareness of Community-Based Long-Term Care and Services, Journal of Hosing For the Elderly, (2008), Vol.22, No.4, pp.404-422, DOI: https://doi.org/10.1080/02763890802458429

[3] Estimation of Future Population, National Statistical Office, http://kosis.kr/statHtml/statHtml.do?orgId=101\&tblId=DT_1BPA401\&vw_cd=MT_ZTITLE\&list_id=A41_10\&seq 
No=\&lang_mode $=$ ko\&language $=k o r \& o b j \_v a r \_i d=\& i t m \_i d=\& c o n n \_p a t h=M T \_Z T I T L E,(2016)$

[4] T. Y. Park, J. S. Lee, J. H. Hyun, Y. J. Park, J. H. Park, H. J. Lee, J. M. Kwon, D. J. Hwang, 衣笠一茂, A. L. Almqvist, L. Dahlgren, E. M. Anbäcken, A. B. Sand, Care Policy in Korea, Japan and Sweden, Yangseowon, ISBN978-89-994-0437-5(93330), (2015)

[5] K. H. Jung, E. N. Kang, Y. K. Lee, N. H. Hwang, C. M. Yang, Analysis and Development Strategy of the Elderly Welfare Policy, Korea Institute for Health and Social Affairs, (2016)

[6] H. Y. Kim, Towards an Ecological Approach to Local Community Research, Korean Journal of Social Welfare Research, (2011), Vol.29, pp.165-190.

[7] H. J. Lee, Social Economy and Community Development: Focusing on the Principles of Innovation, Reciprocity and Cooperation, Korean Journal of Sociology, (2015), Vol.49, No.5, pp.77-111, DOI: 10.21562/kjs.2015.10.49.5.77

[8] H. J. Lee, H. J. Kim, The Meaning and practice of Consumer'Cooperative Welfare - A case study on the Seoul WoolimDure Consumer'Cooperative, Institute for Humanities and Social Sciences, (2015), Vol.16, No.2, pp.311-352, DOI: 10.15818/ihss.2015.16.2.311

[9] J. W. Gong, An Exploratory Study on the Effectiveness of Cooperatives as a Social Service Delivery System, The Korean Journal of Cooperative Studies, (2013), Vol.31, No.2, pp.49-66, DOI: 10.35412/kjcs.2013.31.2.003

[10] M. R. Lee, S. H. Kim, The Interactive Effects of Age Groups and Demographical Characteristics on Self-Integration of Elderly People, Family and Environment Research, (2012), Vol.50, No.3, pp.95-109, DOI: 10.6115/khea.2012.50.3.095 